\title{
Geotechnics and Python to design deep foundations of challenging energy structures
}

\author{
Isabelle C.A. Thomaz ${ }^{1}$, Lucas M. P. da Silva ${ }^{1}$ and Gustavo V. M. Guimarães ${ }^{1}$ \\ ${ }^{1}$ Federal University of Rio de Janeiro, Department of Civil Engineering, 50 Av. Aluisio da Silva Gomes - Novo Cavaleiros, Macaé - RJ, \\ CEP 27930-560, Brazil
}

\section{Introduction}

Special structures such as electrical transmission towers and wind turbines towers transmit all type of loads to the top of foundations (e.g., vertical load, horizontal load, bending moments and torsion moments). Foundations are responsible for further transferring all these loads to the soil. The behavior of these foundations plays an important role in safety and satisfactory performance of the structure. Usually, the loads come from winds, ocean currents and/or pullout on electricity cables. Most geotechnical methods to design deep foundations do not take into account these kinds of loads. Design can be challenging, especially when a significant sum of horizontal and/or pullout action exists. In some cases, it is necessary to design a group of inclined piles to resist such a high laterally load. Over the years, some methods were developed for designing a group of inclined piles. Asplund (1947) and Schiel (1957, 1960, 1970) developed their own methods with particular hypotheses and creating matrix calculous that simplified the problem and became easier to program. Schiel's method helps to design a group of inclined piles with all different kind of loads. This recent research uses Python, a worldwide programming language (Raschka and Mirjalili, 2017), to assist in the mathematical solutions and create a calculous routine to apply Schiel's method in many situations, such as energy structures. Figure 1 shows some of these structures.

\section{Model Description}

Some basics hypotheses of Schiel's method are as follows:

- The pile cap has enough rigidity to distribute its strain comparing to the pile's strain;

- The piles are thin enough not to considerate the bending moment produced by the pile's strain. Indeed, it is not also considerate the earth lateral pressure around the piles. These make the endconditions between the cap and pile as well as the pile and soil become a hinge;

\footnotetext{
*Corresponding author: eng.ithomaz@gmail.com
}

- The axial force in piles is proportional to displacement's projection of pile's top over its axis.

Those three hypotheses of the Schiel method must be respected in all the procedures. The first hypotheses is valid for most of the non-marine structures; the second one is respected when the end condition between the pile and the pile cap is a hinge; the third one is typical of the Hooke's law-based methods, which means the materials have an elastic behavior. Design with the Schiel method establishes that at least one of the piles must be inclined. Other methods can also be applied on the same situations, but they have much more difficult approaches (e.g.: Ilo Costa, 1973, allows different end-conditions between cappile-soil and Cabral, 1982, suppose materials with an elastoplastic behavior).
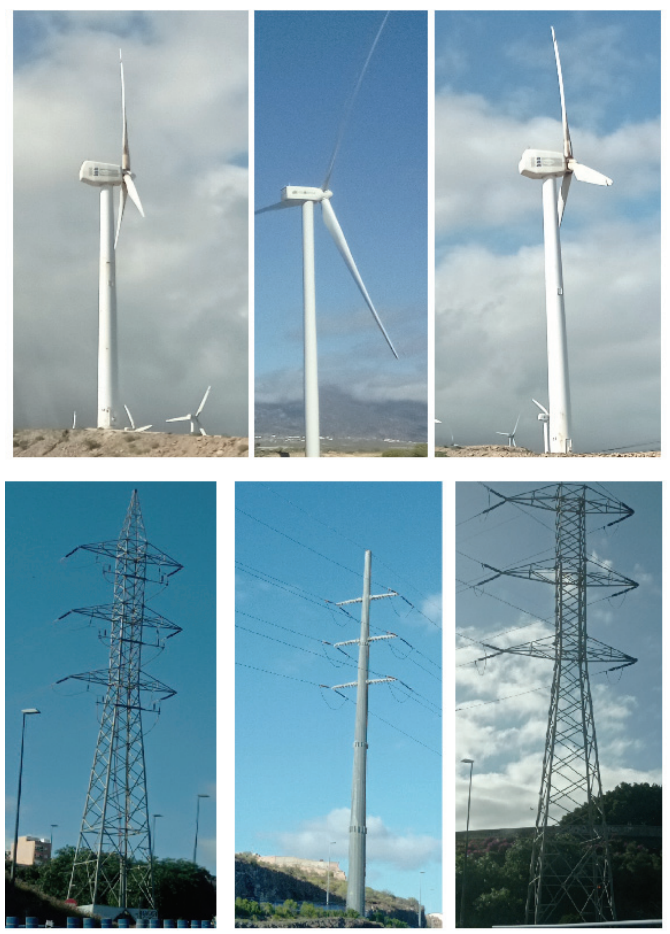

Fig. 1: Wind turbine towers and transmission line towers. 
Table 1: Loads to design a group of inclined piles with Schiel method.

\begin{tabular}{|l|l|l|l|l|l|l|}
\hline & $\mathrm{F}_{\mathrm{x}}(\mathrm{kN})$ & $\mathrm{F}_{\mathrm{y}}(\mathrm{kN})$ & $\mathrm{F}_{\mathrm{z}}(\mathrm{kN})$ & $\mathrm{M}_{\mathrm{x}}(\mathrm{kNm})$ & $\mathrm{M}_{\mathrm{y}}(\mathrm{kNm})$ & $\mathrm{M}_{\mathrm{z}}(\mathrm{kNm})$ \\
\hline Max & 1,427 & 1,588 & $-13,878$ & 141,954 & 133,464 & 8,186 \\
\hline Min & $-1,139$ & $-1,514$ & $-19,394$ & $-142,582$ & $-137,200$ & $-10,211$ \\
\hline
\end{tabular}

Equation 1 gives the loading matrix $[\mathrm{N}]$ at the top of each pile. Where $[\mathrm{R}]$ is the force matrix and $[\mathrm{P}]$ is the cap geometry matrix. $[\mathrm{S}]$ is the global stiffness matrix and si is the relative local stiffness.

$$
N=\left[s_{1} \ldots s_{i}\right] * S^{-1} * R * P
$$

These is one of the situations where Python is a useful feature with NumPy and Pandas libraries. These tools help to calculate the matrix, which is the basis of Schiel's method.

\section{Analyzed Case}

Milititsky (2019) presents a typical general load of wind turbine with $120 \mathrm{~m}$ height. The foundation is proposed as a cylindrical rigid cap with a diameter of $16 \mathrm{~m}$ and $3 \mathrm{~m}$ high and 32 inclined piles with $12.5^{\circ}$ with respect to the $\mathrm{z}$ axis. Due to the hypothesis of Schiel's method, the load in xy direction will not be considerate. Table 1 shows maximum and minimum loads on the top of the cap in $x$, $\mathrm{y}$ and $\mathrm{z}$ axis.

Figure 2 shows the geometry of the foundation analyzed with Schiel's method. The results of the analysis shows all the efforts at the top of each pile. On the analysis of maximum load, 19 piles were submitted to a compressive load and 13 piles were submitted to an uplift load. The maximum compression load on a pile was 2,343 $\mathrm{kN}$. The maximum uplift load on a pile was $-1,480 \mathrm{kN}$. On the analysis of minimum load, 20 piles were submitted to a compressive load and 12 piles were submitted to an uplift load. The maximum compression load on a pile was $2,620 \mathrm{kN}$. The maximum uplift load on a pile was $-1,356 \mathrm{kN}$.

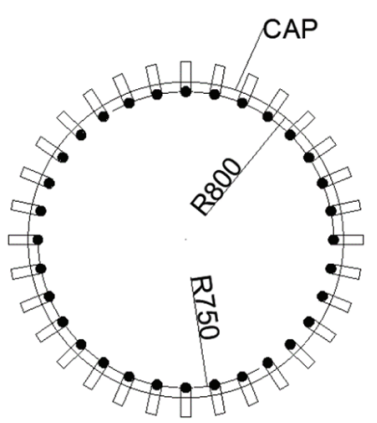

Fig. 2: Foundation of the wind turbine with a rigid cap and a group of 32 inclined piles.

\section{Discussion}

Employment of special energy structures usually improve a challenging foundation design. Due to the huge magnitude of the horizontal loads, bending moments and, sometimes, torsion moments it is worth to design a group of inclined piles when the geotechnical condition allow it.
Python is a tool that combined with Schiel's method become a power feature for design deep foundations.

\section{References}

1. Asplund, S.O.A. (1947). "Study of three-dimensional pile groups", Mémories, Association Internationale des Pouts et Charpentes.

2. Cabral, D.A., (1982). "Análise de estaqueamento pelo método das cargas limites". M.Sc. Thesis COPPE-UFRJ, Rio de Janeiro, Brazil, 158 pp (in portuguese).

3. Costa, I.D.B., (1973). "Estudo elástico de estaqueamentos". M.Sc. Thesis - PUC-RJ, Rio de Janeiro, Brazil, 55pp (in portuguese)..

4. Milititsky, J. (2019). "Fundações de torres: aerogeradores, linhas de transmissão e telecomunicações" (in portuguese).

5. Raschka, S. and Mirjalili, V. (2017). "Python Machine Learning, Machine Learning and Deep Learning with Python, scikit-learn, and TensorFlow". 2nd Edition, Packt Publishing Ltd., UK.

6. Schiel, F., (1957). "Estática dos Estaqueamentos", publicação $\mathrm{n}^{\mathrm{o}}$ 10, Escola de Engenharia de São Carlos, São Paulo, Brazil (in portuguese)..

7. Schiel, F. (1960). "Statik der Pfahlwerke". Berlin: Springer Verlag.

8. Schiel, F. (1970). "Statik der Pfahlwerke, Zweite neubearbeitete Auflage". Berlin: Springer Verlag. 